\title{
Maciej Grabski
}

\section{PROMOCJA MONOGRAFII ZENONA ZŁAKOWSKIEGO SOLIDARNOŚĆ OLSZTYŃSKA W LATACH 1980-1989}

W Warmińsko-Mazurskim Urzędzie Wojewódzkim w Olsztynie, 10 września 2020 r., odbyła się promocja dwutomowej monografii Zenona Złakowskiego, zatytułowanej Solidarność olsztyńska w latach 1980-1989. Publikacja została wydana przez Instytut Północny im. Wojciecha Kętrzyńskiego w Olsztynie. Promocji towarzyszyła wystawa zatytułowana Olsztyńska Sotidarnośc 1980-2020, przygotowana przez pracowników Instytutu (wybór zdjęć i ilustracji: Konrad Bączek, Piotr Bojarski, Tomasz Wyżlic; tekst Ryszard Tomkiewicz).

Spotkanie rozpoczął dyrektor Instytutu Północnego, dr Jerzy Kiełbik, który powitał przybyłych gości, szczególnie ówczesnych działaczy „Solidarności” oraz przypomniał początki niezależnych związków zawodowych w Olsztynie i w regionie. Następnie głos zabrał Władysław Kałudziński, pełnomocnik Wojewody Warmińsko-Mazurskiego ds. osób represjonowanych, który przypomniał realia, w jakich działali członkowie „Solidarności” w latach 80. Wspomnieniami, głównie z początkowego okresu działalności NSZZ „Solidarność” podzielił się także Krzysztof Marek Nowacki, Warmińsko-Mazurski Kurator Oświaty. Na zakończenie tej części spotkania głos zabrał obecny wiceprzewodniczący NSZZ „Solidarność” w Olsztynie - Krzysztof Krzyżaniak. Przypominając dawne dzieje „Solidarności”, zwrócił m.in. uwagę, że dzisiejszy Związek stara się kontynuować tradycje pierwszej „Solidarności”.

W dalszej części spotkania głos zabrał autor publikacji - Zenon Złakowski. Zapoznał zebranych z kulisami powstawania pracy i uzasadnił potrzebę jej wydania w czterdziestą rocznicę utworzenia w kraju (i regionie warmińsko-mazurskim) NSZZ „Solidarność”. Autor podkreślił, że w ten sposób chciał upamiętnić działalność ówczesnych działaczy Związku. Jednocześnie wyraził nadzieję, że dzięki jego opracowaniu olsztyńskie realia tamtych dni, poznają też młodzi ludzie, dla których czas pierwszej „Solidarności”, to już tylko historyczne informacje sprzed czterech

\footnotetext{
Z. Złakowski, Solidarność olsztyńska w latach 1980-1989, t. 1. Opisanie faktów, Olsztyn 2020, s. 386; idem Solidarność olsztyńska w latach 1980-1989, t. 2. Wspomnienia, Olsztyn 2020, s. 415.
} 
dekad. Autor podziękował przybyłym, a w szczególności ówczesnym, aktywnym członkom NSZZ „Solidarność”. Dodał, że wspomnienia i relacje wielu z nich, stanowią treść drugiego tomu monografii.

Na zakończenie głos zabrał Kazimierz Wosiek, dawny działacz „Solidarności”, który podczas uroczystości wręczył Bogusławowi Michałowi Kłosińskiemu odznakę Zasłużonego Działacza Kultury. Wprawdzie odznaczenie to zostało przyznane 13 grudnia 2000 r. przez Ministra Kultury i Dziedzictwa Narodowego Kazimierza Michała Ujazdowskiego, ale wyróżniony nie mógł go wtedy osobiście odebrać.

Spotkanie podsumował Dyrektor Instytutu Północnego im. Wojciecha Kętrzyńskiego.

\section{Maciej Grabski}

Instytut Północny im. Wojciecha Kętrzyńskiego w Olsztynie

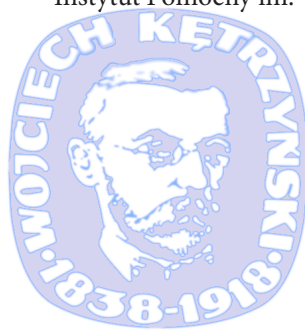

